\title{
LOCAL GOVERNMENT ORGANIZATIONS ACTIVITY IN UZBEKISTAN
}

\author{
Nurmetova Fazilat Ilkhomovna \\ Lecturer at the Department of Theory of Civil Society of Andizhan State University, \\ Andizhan, Republic of Uzbekistan
}

Article DOI: https://doi.org/10.36713/epra4149

\begin{abstract}
In this article is analyzed local government activity in Uzbekistan by the sources and scientific literatures. Besides, research shows that during the years of independence Uzbekistan pays special attention to the modernization of public life and the formation of civil society and these processes, in turn, are aimed at supporting the activities of civil society institutions.
\end{abstract}

KEYWORDS:local government, Uzbekistan, civil society, activity, modernization, process, formation, development.

\section{INTRODUCTION}

During the years of independence Uzbekistan pays special attention to the modernization of public life and the formation of civil society. These processes, in turn, are aimed at supporting the activities of civil society institutions. In particular, the "Strategy of Action for the Five Priorities of Development of the Republic of Uzbekistan in 20172021 " focuses on the development of civil society institutions $[1,38]$. At the same time, paragraph 49 of the State Program "Year of Dialogue with the People and Human Interests" provides for the support of civil society institutions in Uzbekistan by local authorities.

\section{METHODS}

One of the most important tasks in the country today is to create a market-based economy, and the second is to create a representative system of state power and representative bodies of citizens. Therefore, the existing regional, district and city branches of the representative bodies have been preserved, following the principle "Do not demolish the old one before you build a new house". Existing local representative bodies are not new bodies but were formed on the basis of Soviets of people's deputies. It is well known that the Soviets of local People's Deputies, which existed in the former Soviet Union, did not have a clear authority, and the main reason for their inferiority was that the party bodies directly intervened in their work and were elected by their party bodies.

\section{RESULTS AND DISCUSSIONS}

It should be noted that during the period 1990-
1992, when the Constitution of the Republic of Uzbekistan was adopted, several laws were adopted to form the system of local authorities. It should be noted as an example:

- Law on the Status of People's Deputies of the Republic of Uzbekistan, October 31, 1990.

- Law of the Republic of Uzbekistan "On the bases of state independence" of August 31, 1991.

- Law of the Republic of Uzbekistan "On Improvement of the Structure of Executive Bodies of the Republic of Uzbekistan - Management Bodies", November 3, 1990.

- Resolution of the Presidium of the Supreme Council of the Republic of Uzbekistan on November 25, 1991 "On approval of the Provisional Regulations on the Procedure of Electing the Mayor of Tashkent", etc.

On January 4, 1992 the Law "On reorganization of local authorities of the Republic of Uzbekistan" was adopted. This law introduced the post of khokimiyats and khokims, headed by two independent bodies of local authority - the system of representative and executive bodies. The Supreme Soviet granted the status of constitutional law. In 1992, governors were appointed and approved in Tashkent and in 12 provinces, 163 rural districts and 18 municipal districts and 120 municipalities, with their apparatus being established. This year, Uzbekistan has begun practical work on adopting a number of laws and regulations in the field of forming the system of local authorities. These documents include the Constitution of the Republic of Uzbekistan adopted on December 8, 1992, the Laws on Local Government and September 2, 1993, on Local Self-Government Bodies, May 5, 1994. , the 
Law on Elections to City Councils and others.

Chapter 21 of the Constitution of the Republic of Uzbekistan is called "Bases of Local Authority" [2, p.27], where the system, status, functions, order of formation of local public authorities are constitutionally strengthened. According to the Constitution, the previous local representative bodies were renamed into Councils. Regional, district and city Councils of People's Deputies were established to ensure their effective functioning.

Bases of Local Authority - Representative bodies of authority nowadays governed by provincial, district and city councils of people's deputies are issues of their competence in the interests of the state and citizens. The local authorities are: 1) ensuring the rule of law, the rule of law and the security of citizens; 2) economic, social and cultural development of territories; 3) Formation of local budgets; 4) management of the municipal economy; 5) registration of acts of civil status, etc. Apart from these, there are also self-governing bodies in urban, rural and aulous communities, and their role in building a democratic legal state and civil society is increasing.

It should be noted that before the adoption of the current Constitution of Uzbekistan, there is a three-tier system of local representative bodies:

1) Councils (Soviets) of regions and the city of Tashkent are the highest level.

2) district, city (town) Kenghashes of People's Deputies;

3) Councils of People's Deputies of rural, settlement, aul - lower level;

The constitution has strengthened the twotiered system of local representative bodies, which means that the lower level has been removed. Local self-government bodies will be replaced by them. This is reflected in the Law "On the Bases of Local Government". Thus, in the Constitution of the Republic of Uzbekistan, local authorities are divided into two independent bodies: representative and executive. As it is seen from the aforementioned data, local representative bodies - councils of people's deputies. They operate on a collective basis. Session is the main organizational and legal form of work of Kengash of people's deputies.

The law "On elections to provincial, district and city (town) Kenghashes of People's Deputies" elected citizens to 21 years of age in representative bodies. The elections are held on a multiparty and alternative basis. Deputies to provincial and Tashkent city councils shall be elected not more than 60 deputies, and not more than 30 deputies to district and city Kenghashes. At the same time, the executive power of the republic includes the khokim and his executive apparatus. The khokim is the highest official in the relevant area. According to Article 101 of the Constitution of the Republic of Uzbekistan, the term of office of khokims is five years. According to Article 102 of the Constitution of the Republic of Uzbekistan, "The khokims of regions, districts, cities and towns shall be headed by the representative and executive authorities, respectively. The khokim of region and the city of Tashkent shall be appointed and relieved of his post by the President of the Republic of Uzbekistan in accordance with the law. The khokims of districts, cities and towns shall be appointed and dismissed by the khokim of the relevant region, with subsequent confirmation by the appropriate Soviet of People's Deputies. The khokims of city districts shall be appointed and relieved of their posts by the khokim of the relevant city and approved by the city Kenghash of people's deputies. The khokims of towns subordinate to districts shall be appointed and dismissed by the khokim of the district and approved by the district Kenghash of peopleэs deputies "[2, p.28].

\section{CONCLUSION}

Khokimiyats were established in districts and towns subordinated to the city, where the representative bodies were not formed, and their apparatus was established. Khokims of regions and the city of Tashkent are the representatives of the President of the Republic of Uzbekistan in these areas. The khokims of Tashkent city districts are representatives of the city Khokim. The activity of local public authorities is a complex structure and is regulated by the Constitution of the Republic of Uzbekistan, the Law on Local Government [3, p.29] and other legislative acts of the Republic of Uzbekistan. These bodies interact with law enforcement agencies, the prosecutor's office, the police, and the law enforcement agencies.

It can be concluded that the local authorities in exercising their powers are guided by democratic principles. These bodies work in the same manner as law enforcement agencies, and gradually coordinate their work.

\section{REFERENCES}

1. Scientific-methodical brochure on the study of the State program on implementation of the Strategy of Action on the five priority directions of development of the Republic of Uzbekistan in 2017-2021.

2. The Constitution of the Republic of Uzbekistan.Tashkent: Uzbekistan, 2016.

3. Theory and practice of building a democratic society in Uzbekistan - Tashkent: Navruz, 2014.

4. The New History of Uzbekistan. History of independent Uzbekistan.-Tashkent: Shark, 2000. - p.241. 